\title{
Silviculture for non-timber forest product management: challenges and opportunities for sustainable forest management ${ }^{1}$
}

\author{
Krishna H. Gautam² and Teiji Watanabe ${ }^{3}$
}

\begin{abstract}
Recent concerns regarding non-timber forest product (NTFP) management are focused on raw material production. But NTFP ought to be viewed from the perspective of ecological processes, cultural heritage, livelihood of local people, economic values and incentives for forest management. This broader role for NTFP cannot be realised by simply domesticating a few species. Integration of NTFP in forest management is necessary in order to achieve sustainable forestry. Because forestry technologies are developed with timber values uppermost, it is vital to develop forest management technologies that take into account both timber and non-timber values. Global examples show that traditional knowledge could play a vital role while developing silvicultural regimes, and in situ experimentation will strengthen the regimes. Guidelines for ethnobotanical studies are briefly presented.
\end{abstract}

Key words: cultural heritage, ecological processes, ethnosilviculture, livelihoods, non-timber forest product, sustainable forestry

Les produits forestiers non ligneux (PFNL) ont attiré récemment l'attention en foresterie. Malgré que l'intérêt principal des PFNL ait porté dernièrement sur les ressources brutes, l'importance des PFNL doit être visualisée selon la perspective des processus écologiques, de l'héritage culturel, des habitudes de vie, des valeurs économiques et des mesures incitatives d'aménagement forestier. Une telle importance ne peut se refléter par la simple domestication de quelques espèces. L'intégration des PFNL en aménagement forestier est nécessaire pour atteindre la foresterie durable. Même si les technologies forestières sont généralement développées pour tenir compte seulement des ressources ligneuses, il est nécessaire d'élaborer des techniques d'aménagement forestier qui considèrent autant les ressources ligneuses que non ligneuses. Les instances mondiales indiquent que les connaissances traditionnelles pourraient jouer un rôle vital dans l'élaboration de ces technologies, par ex. en fournissant une assise à la recherche scientifique. Des méthodologies sont suggérées en se basant sur de récentes études ethnobotaniques.

Mots-clés : héritage culturel, processus écologiques, ethnosylviculture, modes de vie, produit forestier non ligneux, foresterie durable

\section{Introduction}

The evolution of industrial forestry over the past few centuries focused on timber production and overshadowed nontimber forest products (NTFP) that were important to human development for generations. Recently, this deterioration of NTFP has become a matter of great concern for foresters, scientists, environmentalists, industrialists and commercial entrepreneurs (Salick et al. 1995, Ruiz-Perez and Arnold 1996, Lund et al. 1998, Davidson-Hunt et al. 2001, Emery and McLain 2001). Marketable NTFP - as opposed to those used at the subsistence level in rural areas-have mainly fuelled recent concerns. Demand for marketable NTFP is expanding and has led to severe depletion of NTFP species in the forests. Accordingly, many such species have been officially upgraded to the status of rare, threatened or endangered. Increasing the supply of these products without compromising the quality of forests is a new challenge for sustainable forestry.

Expanding commercial demand for some NTFP species has inspired scientific communities to study the prospects for large-scale production, and accordingly progress in domesticating/cultivating some NTFP species has been achieved. But mere domestication of a few species may not reduce collection

\footnotetext{
${ }^{1}$ Based on a poster presentation to the Canadian Institute of Forestry, North Bay, Ontario, October, 2002.

${ }^{2}$ Research Fellow, Graduate School of Environmental Earth Science, Hokkaido University, Sapporo, Japan.

${ }^{3}$ Associate Professor, Graduate School of Environmental Earth Science, Hokkaido University, Sapporo, Japan.
}

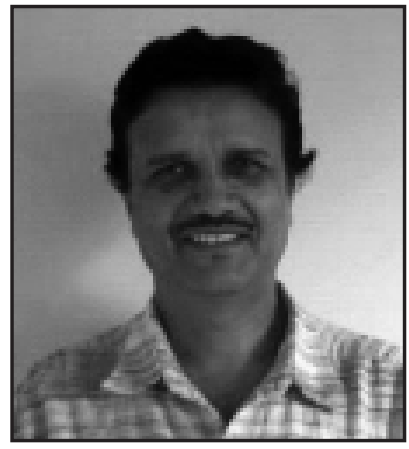

Krishna H. Gautam

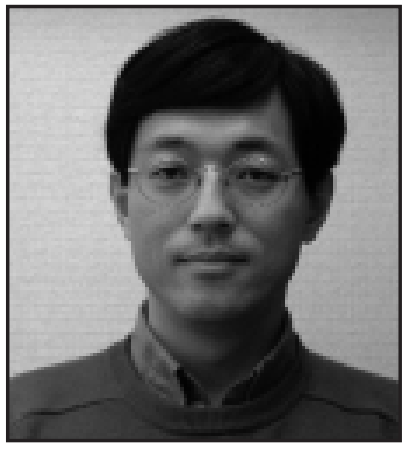

Teiii Watanabe from the wild and subsequent depletion of reserves. Rural peoples' livelihood cannot be sustained without these products yetout of economic necessity- they continue to increase collection from the wild. The only way to reduce this ravaging of forests is to offer local people genuine alternatives through which they can sustain or improve their livelihoods.

It is important to view NTFP as something more than commercial items needed to sustain industries; they must be seen as part of an ecosystem with a diverse array of uses and values. In this context, forest management needs to explore productive uses of forests and maintain their capacity to produce timber and NTFP. Forest management practices and technologies need to be reoriented not only to increasing timber productivity but also to the management of NTFP in a sustainable manner. This approach takes the forest management 
paradigm beyond trees, and toward consideration of all life forms of forest ecology. This evolution is essentially a shift in focus with the objectives of forest management taking on new dimensions that would compel foresters to look for appropriate silvicultural methods and technologies to manage both timber and NTFP.

Silviculture is a dynamic field where ecological knowledge and social and economic issues converge. The product's role and importance in ecological and sociological perspectives must be understood in order to craft a proper silvicultural regime for the product. But the present reality is that research-based ecological and biological knowledge of NTFP that includes shrubs, herbs, vine, grass and fungi is very limited (Davidson-Hunt et al. 2001).

In this paper, we review the importance of NTFP from different perspectives, which are crucial prerequisites for crafting silvicultural regimes for NTFP management.

\section{Importance of NTFP}

Besides raw materials for an ever-increasing forest industry, NTFP have the following importance in local, regional and global contexts:

Sustaining ecological processes. Complex combinations of facilitation and competition interactions have been identified in a number of plant communities (Callaway and Walker 1997, Rebel 2000, Tielborger and Kadmon 2000, Pugnaire and Luque 2001, Sans et al. 2002, Totland and Esaete 2002). Any disturbance of plant communities may affect ecological processes. Non-timber forest products are linked to the ecological processes of disturbance and succession in the forests (Davidson-Hunt and Berkes 2001). Every species has ecological specifications and grows and survives in natural associations, and disappearance (due to over-harvesting or other reasons) of one or more species from their natural habitats may have farreaching consequences for the habitat itself. It is not only that a particular product may start to decline but that this may also affect other life forms and species. Thus, harvesting any product from forests may have a significant role in sustaining ecological processes and maintaining biodiversity. The issue is very sensitive and needs to be given serious consideration while making any prescription for NTFP management.

Sustaining cultural heritage. The indigenous peoples of Canada have culturally defined values that reach beyond the economic potential of various species (Turner 2001). In some areas and/or communities, forests are managed for cultural importance (Powell 2000, Byers et al. 2001). Different communities may have different cultural importance to different products/species. In such a context, indigenous peoples' culture can be strengthened through NTFP management (Bombay 2001). However, very little attention has been paid to social and cultural aspects of the industrial NTFP (Turner 2001, Taylor n.d.). Commercialisation of culturally important species may bring dissatisfaction among community members, who may protest against such activities while challenging the sustainability of forest management. Thus, appreciation of cultural integrity is a vital element of forest sustainability.

Sustaining livelihood. Most NTFP are collected by poor people residing within and around natural habitats for their liveli- hood (Gautam 2001, Conroy et al. 2002, Shanley and Swingland 2002). Despite the significance of NTFP resources in the livelihoods of diverse ethnic communities, these people increasingly find themselves marginalized on the fringes of modern society and the development process. NTFP development processes are seen as being beyond their capabilities (Conroy et al. 2002, Shanley and Swingland 2002). Furthermore, medicinal plants in their natural habitats are crucial for their health, as modern health services are still far from their reach. Any negligence in appreciating such values may challenge the sustainability of forest management.

Enhancing forestry income. NTFP management represents the most immediate and economically competitive method for integrating the use and conservation of forests (Myers 1988, Peters et al. 1989), eventually leading to sustainable forest management. NTFP in rural areas represent a large share of regional and national economies (Hyde and Amacher 1996), but their value is little appreciated in forestry management, and the resulting under-valuation has caused policy makers to discount the importance of the forestry sector. If NTFP are accorded a just value, this may attract more resources to forestry.

Providing incentives. NTFP may actually provide a vehicle for forest management. Bamboo, fodder, and fibre grasses act as catalysts between villagers and the forestry authority in joint forest management programmes in India. Ensuring a steady supply of subsistence products from forests has turned the open access forest into common property in Nepal. NTFP could generate many incentives for mobilizing people in sustainable forest management.

Thus, NTFP are important both ecologically and socially. Silviculture, based on up-to-date research on the biology and ecology of species, needs to mesh with the given social, economic and cultural variants in a region in order to attain sustainable forestry. The challenging task for the forester is to craft it with care.

\section{Crafting Silvicultural Regimes for NTFP}

Acquiring silvicultural knowledge is the initial stage in developing any new regime. Silvicultural knowledge of NTFP species can be acquired through traditional knowledge, scientific research or a combination of both (Duchesne et al. 2001). The biology and ecology of NTFP species are given insufficient study in scientific forestry research. On the other hand, traditional ecological knowledge may play a significant basis in devising a silvicultural system.

An ethnosilvicultural study (Gautam 2001) in Nepal revealed that local people have enormous knowledge of the abundance and distribution of species, associate species (complementary, deleterious, indicator), dispersal mechanism, phenology, propagation characteristics, site quality, and other general features of most of the species in their forests. Indigenous people demonstrate similar knowledge (habitat enhancement and diversification, controlled burning and clearing, selective and strategically timed harvesting, increasing productivity through pruning, coppicing, tilling, and control of weeds and pests) in boreal forests (Lund et al. 1998, Marles 2001, Turner 2001). Love and Jones (2001) indicated the existence of indigenous knowledge in temperate forest ecosystems. Studies (RuizPerez and Arnold 1996, Davidson-Hunt and Berkes 2001) revealed the extent of indigenous knowledge of NTFP management in tropical forests. All of this global evidence indicates the enor- 
mous knowledge, including silvicultural expertise, among indigenous people. Forest managers and scientists must strive to take advantage of such ethnosilvicultural knowledge while developing silvicultural regimes for NTFP management.

Emery and Zasada (2001) have drafted the process for incorporating NTFP into silvicultural systems through the use of local knowledge. Marles (2001) has developed a practicable method for ethnobotanical research, very relevant for enhancing ethnosilvicultural research. Gautam (2001) has documented a detailed process for acquiring ethnosilvicultural knowledge from community forest users groups.

All socio-economic groups based on ethnicity, age, gender, land-holding, and elite status were involved in an ethnosilvicultural study in Nepal (Gautam 2001). In any of these processes, the participation of all groups in the community is essential, as different groups are the guardians of different types of information. However, community members identify the most resourceful among them in particular forestry issues. Meeting the concerned people individually and/or in groups may refine the information. Further triangulation can be done with other groups and joint group meetings. An exchange of knowledge with local people can provide a good opportunity to improve information.

In situ experiments will provide useful information with which to modify future practices. Thus, a combination of local ecological knowledge and scientific research will produce the silvicultural regime appropriate for a given social context, and eventually contribute significantly to the sustainable forestry.

\section{Acknowledgements}

The authors gratefully acknowledge the valuable comments and suggestions of Prof. Lionel Lumb, Carleton University, Ottawa, Canada.

\section{References}

Bombay, H.M. 2001. Introductory remarks from the National Aboriginal Forestry Association. In I. Davidson-Hunt, L. Duchesne and J. Zasada (eds.). Forest communities in the third millennium: linking research, business and policy towards a sustainable non-timber forest product sector. pp. 14-16. USDA Forest Service.

Byers, B.A., R.N. Cunliffe and A.T. Hudak. 2001. Linking the conservation of culture and nature: a case study of sacred forests in Zimbabwe. Human Ecology 29(2): 187-218.

Callaway, R.M. and L.R. Walker. 1997. Competition and facilitation: A synthetic approach to interactions in plant community. Ecology 78(7): 1958-1965.

Conroy, C., A. Mishra and A. Rai. 2002. Learning from self-initiated community forest management in Orissa, India. Forest Policy and Economics 4(3): 227-237.

Davidson-Hunt, I. and F. Berkes. 2001. Changing resource management paradigms, traditional ecological knowledge, and nontimber forest products. In I. Davidson-Hunt, L. Duchesne and J. Zasada (eds.). Forest communities in the third millennium: linking research, business and policy towards a sustainable non-timber forest product sector. pp. 78-92. USDA Forest Service.

Davidson-Hunt, I., L.C. Duchesne and J. Zasada (eds.). 2001. Forest communities in the third millennium: linking research, business and policy towards a sustainable non-timber forest product sector. USDA Forest Service.

Duchesne, L.C., J. Zasada and I. Davidson-Hunt. 2001. Ecological and biological considerations for sustainable management of nontimber forest products in northern forests. In I. Davidson-Hunt, L. Duchesne and J. Zasada (eds.). Forest communities in the third millennium: linking research, business and policy towards a sustainable non-timber forest product sector. pp. 102-109. USDA Forest Service.
Emery, M.R. and R. McLain. (eds.) 2001. Non-timber forest products, medicinal herbs, fungi, edible fruits and nuts and other natural products from forest. Food Products Press (Haworth Press), New York. 176 p.

Emery, M.R. and J. Zasada. 2001. Silviculture and nontimber forest products: extending the benefits of forest management. pp. 10-13. Timberline 2001, New England Forestry Foundation.

Gautam, K.H. 2001. Lopping regimes in community-managed sal (Shorea robusta) forests of Nepal: prospects for multiple-product silviculture for community forestry. $\mathrm{PhD}$ thesis, University of Canterbury, New Zealand.

Hyde, W.F. and G.S. Amacher. 1996. Applications of environmental accounting and the new household economics: new technical economic issues with a common theme in forestry. Forest Ecology and Management 83: 137-148.

Love, T. and E.T. Jones. 2001. Why is non-timber forest product harvesting an issue? Excluding local knowledge and the paradigm crisis of temperate forestry. Journal of Sustainable Forestry 13(3-4): 105-121.

Lund, H.G, B. Pajari and M. Korhonen (eds.). 1998. Sustainable Development of Non-wood Goods and Benefits from Boreal and Cold Temperate Forests. European Forest Institute.

Marles, R.J. 2001. Non-timber forest products and aboriginal traditional knowledge. In I. Davidson-Hunt, L. Duchesne and J. Zasada (eds.). Forest communities in the third millennium: linking research, business and policy towards a sustainable non-timber forest product sector. pp. 53-65. USDA Forest Service.

Myers, N. 1988. Tropical forests: much more than stocks of wood. Journal of Tropical Ecology 4: 209-221.

Peters, C.M., A.H. Gentry and R.O. Medelsohn. 1989. Valuation of Amazonia rain forest. Nature 339: 656.

Powell, J. 2000. Expanding horizons: environmental and cultural values within natural boundaries. International Journal of Heritage Studies 6(1): 49-65.

Pugnaire, F.I. and M.T. Luque. 2001. Changes in plant interactions along a gradient of environmental stress. Oikos 93(1): 42-49.

Rebel, F. 2000. Competition and coexistence of rhizomatous perennial plants along a nutrient gradient. Plant Ecology 147(1): 77-94. Ruiz-Perez, M. and J.E.M. Arnold (eds.). 1996. Current Issues in Non-timber Forest Products Research. CIFOR-ODA.

Salick, J., A. Mejia and T. Anderson. 1995. Non-timber forest products integrated with natural forest managment, Rio San Juan, Nicaragua. Ecological Applications 5(4): 878-895.

Sans, F.X., J. Escarre, J. Lepart and F. Hopkins. 2002. Positive vs negative interactions in Picres hieracioides L., a mid-successional species of Mediterranean secondary succession. Plant Ecology 162(1): 109-122.

Shanley, P. and I.R. Swingland. 2002. The faint promise of a distant market: a survey of Belem's trade in non-timber forest products. Biodiversity and Conservation 11(4): 615-636.

Taylor, D.A. (n.d.). Requisites for thriving rural non-wood forest product enterprises. www.fao.org/docrep/x2450e/x2450203.htm.

Tielborger, K. and R. Kadmon. 2000. Indirect effects in a desert plant community: is competition among annuals more intense under shrub canopies. Plant Ecology 150(1-2): 53-63.

Totland, O. and J. Esaete. 2002. Effects of willow canopies on plant species performance in a low-alpine community. Plant Ecology 161(2): 157-166.

Turner, N.J. 2001. "Keeping it living": applications and relevance of traditional plant management in British Columbia to sustainable harvesting of non-timber forest product. In I. Davidson-Hunt, L. Duchesne and J. Zasada (eds.). Forest communities in the third millennium: linking research, business and policy towards a sustainable non-timber forest product sector. pp. 66-77. USDA Forest Service.

Zasada, J. 2002. Non-timber forest products and implication for forest managers: birch and birch bark. University of Minnesota Extension Service, Web document 20/08/2002 pg. 3. 